\title{
ガルバニ一電流によると思われた舌炎症例
}

\author{
藤原 裕美・青木 正則・川口 和幸 \\ 工田 昌也・平川 勝洋・原田 康夫
}

\section{Glossitis Suspected of Being Caused by Galvanic Current}

\author{
Yumi Fujiwara, Masanori Aoki, Kazuyuki Kawaguchi, \\ Masaya Takumida, Katsuhiro Hirakawa and Yasuo Harada
}

(Hiroshima University)

A galvanic current may be caused in the oral cavity when two or more dissimilar metallic repair materials are present, and it is well known among dentists that severe pain, called "galvanic pain", may result. We report two cases of glossitis thought to have been caused by oral galvanism. We measured the galvanic current in patients with glossitis and found significantly larger electric currents in the patients than in controls. We suspect that oral galvanism is the cause of glossitis when the conditions are as follows: 1) Anemia, medications, mechanical stimulation by dental repair, zinc deficiency, etc. have been ruled out ; 2) Currents greater than five micro-amperes are demonstrated.

Key words: glossitis, galvanic current, oral galvanism, electrogalvanism

\section{緒言}

口腔内には唾液や組織間液などの電解質液が 存在している。その中に異なる種類の金属から なる歯科材料が装着されると, それぞれの金属 のイオン化傾向が異なるために起電力を生じ, 口腔内の組織にガルバニ一電流と呼ばれる電流 が流れる。これを図 1 のボルタの電池と対比す ると, 金属歯科材料が電極, 唾液及び組織間液 が電解質液, 口腔内軟部組織が抵抗に相当する. この電流により，ガルバニー疼痛と呼ばれる歯 や口腔内の痛久が起きることは歯科領域では広 く知られている112)が，今回我々はガルバニ電流により舌炎を生じたと思われた症例を経験 したので報告する。

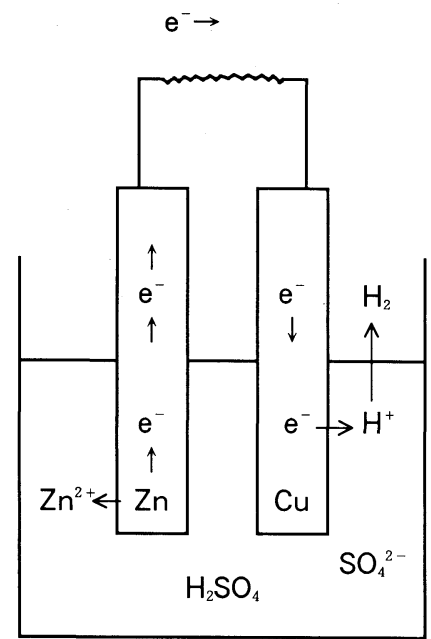

図1ボルタの電池 


\section{症例 \\ 症例 1.57 歳, 女性.}

主訴：左舌縁部痛.

既往歴：20歳頃結核, 虫垂炎.

家族歴：特記すべきことなし.

現病歴：1983年 8 月初旬, 近医歯科飞て左下 顎歯の治療を受けた直後から左舌縁部に痛みを 覚えるよらになった。機械的刺激による痛みを 疑われ，治療した歯が舌に当たらないよう歯を 削るなどの治療を受けたが症状が改善しないた め，1984年 1 月 5 日当科を受診した。

現症 : 左舌縁に発赤を認め, 舌炎と診断した。 病変部位に対する $\mid 6$ に金冠, $\sqrt{6}$ にアマルガム が装着されていた。 三和マルチテスターCX 505 にて両歯科材料間の電流を測定すると, 最 大 $8 \mu \mathrm{A}$ の電流が流れていた(図 2 ). この電流 は接触瞬間時に最大值をとり, 以後減衰する傾 向を認めた。他に耳鼻咽喉, 全身状態に著变を 認めなかった。

経過：病歷拉よび所見からガルバニー電流に より舌炎を生じたものと考元て歯科治療を勧め, 耳鼻科的な治療は特に行わなかった。近医歯科 で両歯の歯科材料を統一したところ，直後より
症状は消失した。

症例 2 . 9 歳, 男性.

主訴: 左舌縁部痛.

既往歴 : 特記すべきことなし.

家族歴 : 特記すべきことなし.

現病歴：1983年春より, 舌及び口唇の痛みを 反復していた。 また舌の中央にアフタ形成を繰 り返し，増悪時に近医内科を受診し硝酸銀焼灼 等の治療を受けるも改善せず，1986年 1 月 16 日 より再び左舌縁の痛みが増強したため， 3 月 18 日当科を受診した。

現症 : 左舌縁に発赤を認めるのみであった。 54， 45 Kアマルガムが装着されて扣り， 電流を測定したところ最大 $5 \mu \mathrm{A}$ の電流が流れ ていた（図 3 )。他に耳鼻咽喉, 全身状態に著変 を認めなかった。

経過：症例 1 と同様歯科治療を勧めたところ, 歯科材料を統一した数日後より症状は消失した。

\section{考察}

口腔内の異なる金属により電気的現象が起き る可能性についての報告は, 我々の検索し得た 限りでは，1878年の Chase ${ }^{3)}$ ののが初めての ようである。この中で彼は補綴された歯はすべ

\section{U一金冠}

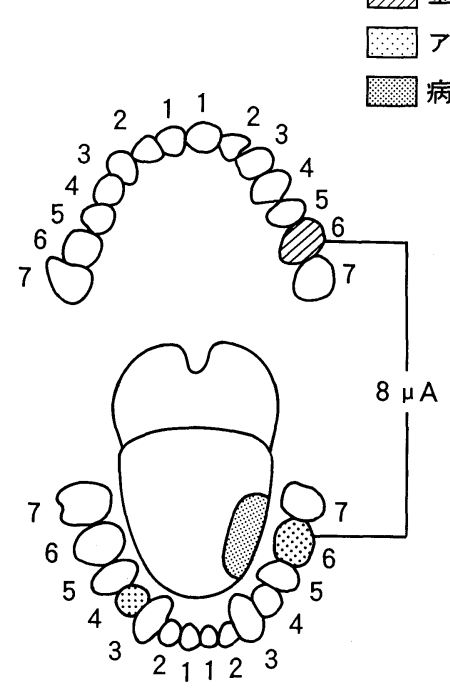

図 2 症例 1 の口腔内模式図

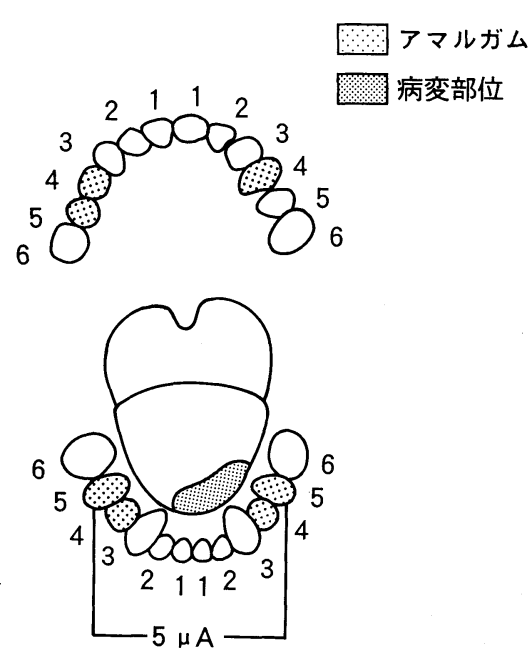

図 3 症例 2 の口腔内模式図 
て酸性の喠液のもとではガルバニー電池になり らると述べている. 以来同様の報告が散見され るよらになったが，その汪とんどはそうした現 象の起さる可能性に言及するか, 実験的なデー タを提示するにとどまっていだ). Palmer5) は 金を口腔内に装着することが最も電池を形成す る可能性が高いと考光たが, Mayer6)のように 口内ガルバニ一電流に対して否定的なものや, Grant ${ }^{7)}$ のように電流による刺激はむしろ有益 であるとしたものもあり，その評価については 混乱がみられた。

1930年代に，Lain らが精力的に症例を蓄積 するに及んで4)899)，同様の報告が多くみられる ようになり10) 14)， 口腔内ガルバニズムについ ての論議も活発化したが，本邦では汪とんど注 目されなかった。

1960年代になると, Phillips らの実験的に口 腔内病变を作製するのに失敗したとの報告 p15)16), Bergman らの口腔内に愁訴を持つもの とそうでないもののガルバニー電流を測定した

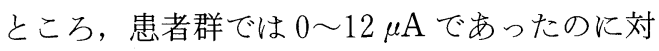
し, 対照群では $0 \sim 36 \mu \mathrm{A}$ と差を認めなかった との報告など17)否定的な見解が多くなり，近 年ではガルバニズムと口腔内病変の関係につい て研究した報告は汪とんど見られていない．

しかし口腔内に電流が流れる場合に生じらる 症状については電気味覚検査を考兄てみれば分 かりやすいであろら．舌に端子を当てて通電す ると，患者は金属味を感じることもあり，ピリ ピリ，チリチリといった言葉で刺激を表現する こともある.ガルバニ一電流が流れている場合 には，こうした症状が生じらるわけである.

著者の一人原田は, 難治性の舌炎が歯科治療 後劇的に軽快した症例に遭遇したのをきっかけ にガルバニ一電流に注目し, 口腔内病変との関 係を明らかにするため, 舌炎症例での口腔内電 流の測定を試みてきたが，その過程でガルバ ニ一電流が病変や症状の発現に関与したと思わ れる症例がかなり存在した。すなわち, 口腔内 処置やビタミン剤投与によっても軽快しない難
治性の舌炎や不定愁訴で, 貧血, 亜鉛欠乏, 降 圧剂投与, 消化器疾患他の基礎疾患などの舌炎 の原因と考兄られる要因がなく， 口腔内の歯科 材料間に電流が流れていた例である。それらの 年齢，性別を図 4 に示す. 1981年から1989年ま での 9 年間に34例あり, 男性 5, 女性 29 之女性 に多く, 年齢では40代から60代に多かった.

これらの患者群のガルバニ一電流の值と, 口 腔内に愁訴を持たない成人男女のガルバニー電 流の值を年齢別にプロットしたのが図 5 である。 電流の值は患者群で $4.6 \pm 1.4 \mu \mathrm{A}$, 対照群で $1.2 \pm 1.5 \mu \mathrm{A}$ と, 患者群で有為に大きい電流が 流れていた。 また，同年代であれば電流量が大 きいものに症状が発現し, 同程度の電流が流れ ていても高齢者に症状が現れる傾向が見られた．

こらした症例には歯科材料を統一寸るよう勧 めたが, 特に $5 \mu \mathrm{A}$ 以上の症例で症状が消失す る例が多かった。これらの経験から我々は, 次 のような症例でガルバニー電流の関与を疑って いる.

1 ）難治性の舌炎または舌に関する不定愁訴 で, 薬剂性, 貧血, 亜鉛欠乏症等の原因が除外 できるもの.

2 ）口腔内に異なる 2 種類以上の金属が装着 され，その間に概ね $5 \mu \mathrm{A}$ 以上の電流が流れて

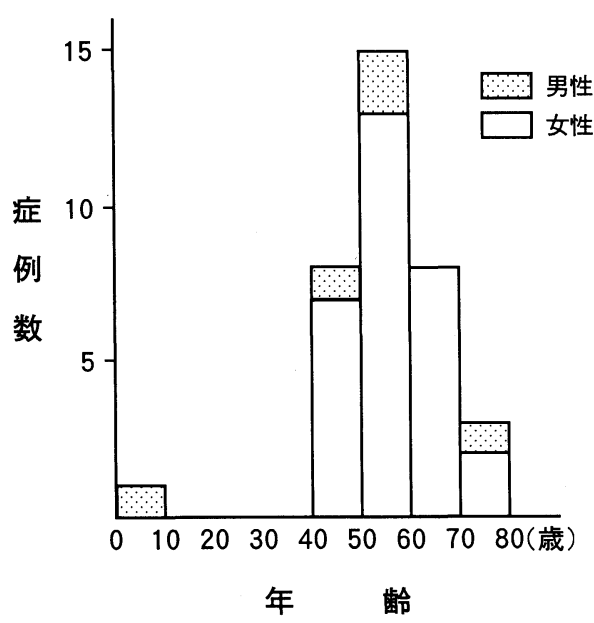

図4 症例群の年齢と性別 
いるもの．

ガルバニー電流の測定に関しては，いまだに 定型的な方法はないよらである。我々は三和マ ルチテスターCX505(図 6)を用い, 患者の歯 科材料に電極をあてて直接電流を測定している が，口腔内に実際に流れる電流量は，金属の種 類の違いによる電位差だけでなく，両金属の口 腔内に持ける位置関係, 個体の組織抵抗や唾液 の性状などにより決定されると考兄られるため, 電流計で直接測定された電流が常に両歯科材料 間を流れているとは限らないまた同量の電流 が流れても，個体の感受性の差により，病変の 生じ方にも差があると考兄られる。

Lain らは我々と同様に直接歯科材料間の電 流を測定し，4〜10 $\mu \mathrm{A}$ でも潰瘍や白板症を生 じたと報告している18). Mumford は電位差と 組織抵抗から実験的に口腔内に流孔る電流量を 算出し，0.5〜 50 $\mu \mathrm{A}$ であろうと述べている ${ }^{19) .}$
岩田は金属間の電位差は唾液の $\mathrm{pH}$ が酸性に傾 く注ど大きくなると述べているが20), Schriever らは唾液の $\mathrm{pH}$ と電位差の間には相関を認めな いと述べている21). 今野らは女性では加齢と共 に有意に唾液の分泌量が減少していると報告し て扮り ${ }^{22)}$, 我々の症例に中年女性が多くみられ

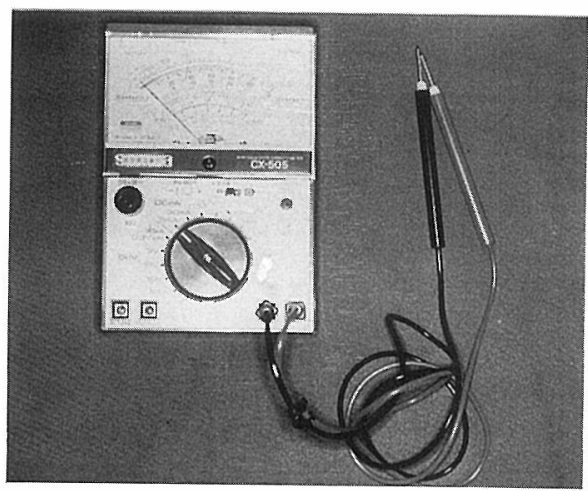

図 6 三和マルチテスターCX505

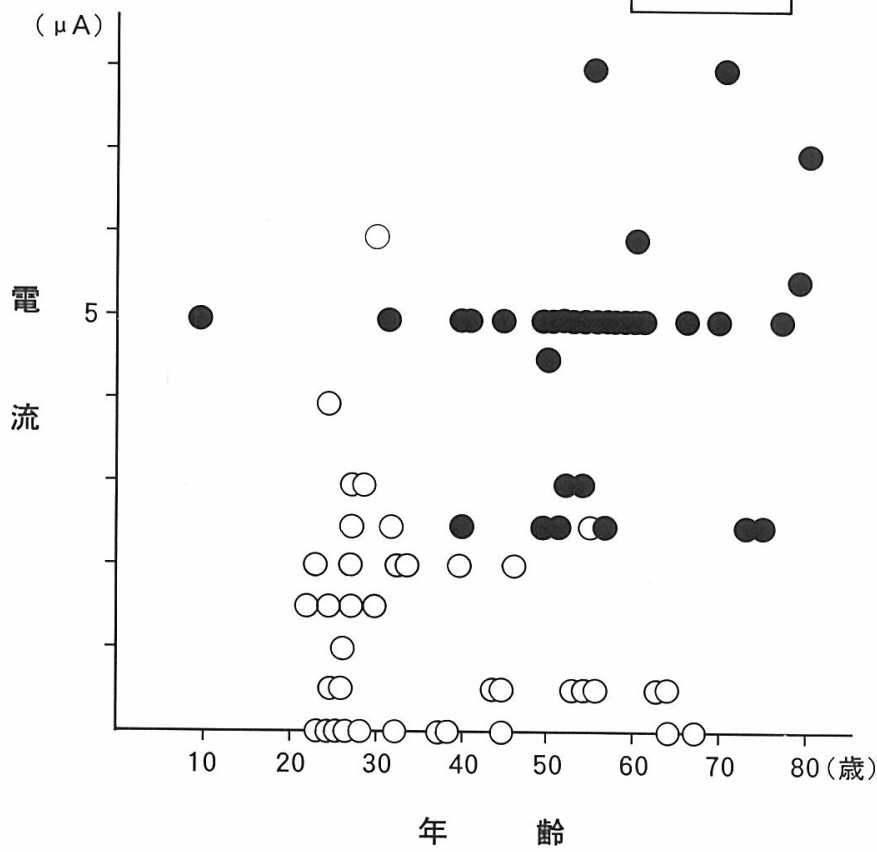

図 5 症例群と対照群の年龄別電流 
た事も考兄合わせると, 唾液の性状や量が個体 の感受性や電流量に及活す影響についても, さ らに研究が必要であろらと考光ている。

近年, 食生活を中心とする生活習慣の変化に 伴い, アレルギー性疾患の増加が問題となって いる。金属アレルギーによる扁平苔痽や，掌蹠 膿胞症なども注目されるよらになってきている が，その感作抗原として，歯科材料も大きな役 割を果たしていると考えられる。金属イオンは, ごく微量でも蛋白と結合することにより，強い 抗原性を発揮することが知られている。不適切 な組合せによりガルバニー電流が流れるといら ことは，金属の溶出が起きることを意味して掠 り，アレルダンとなりらる可能性も増大すると 考えられる.

我々が歯科治療を勧めても，歯科医の理解が 得られず治療されなかった例もあったが，今後 はこうした種々の観点から， 口腔内の歯科材料 に対する各界の関心を惹起することが必要と思 われる。

\section{結 語}

ガルバニ一電流により舌炎を発症したと思わ れた症例を経験したので若干の文献的考察を加 え報告した。これまでガルバニ一電流による口 腔内病変の発現には，あまり注目されていなか ったが，今後は歯科材料に注目することが必要 と思われた。

歯科材料について御教授いただいた広島大学歯学 部第 1 補経学教室講師佐藤裕二先生飞深謝致し未す.

な扮本論文の要旨は第 2 回口腔咽頭科学会および 日本耳鼻咽喉科学会第 15 回中国四国地方部会連合会 で口演した。

\section{参考文献}

1）桃井保子：ガルバニ一電流の発生機構に関する 新しい考察. 日歯保誌 $27: 1 ； 20 \sim 36,1984$.

2）吉田高稔: ガルバニ一電流発生機構の解明. 日 歯保誌 $28: 2 ； 492 \sim 508,1985$.

3) Chase HS : Some observations and experiments connected with oral electricity. American Journal of Dental Science 12:18 23,
$1878 \sim 1879$.

4) Lain ES and Caughron GS : Electrogalvanic phenomena of the oral cavity caused by dissimilar metallic restorations. J Am Dent Assoc 23 : 1641 1652, 1936.

5) Palmer SB : Dental decay and filling materials considered in their electrical relations. American Journal of Dental Science 12 : 105 111, $1878 \sim 1879$.

6) Mayer $\mathrm{C}:$ No battery in tooth. Dental Advertizer $21: 103 \sim 107,1880$.

7) Grant RC : Galvanism, gold, amalgam and Hahnemanian theory. Dental Digest $8: 1110$ $\sim 1122,1902$.

8) Lain ES : Chemical and electrolytic lesions of mouth caused by artificial dentures. Arch Dermat \& Syph $25: 21 \sim 31,1932$.

9) Lain ES : Electrogalvanic lesions of oral cavity produced by metallic dentures. JAMA 100 : 717 720, 1933.

10) Hollander L : Galvanic burns of oral mucosa. JAMA $99: 383,1932$.

11) Hyams BL : Electrogalvanic compatibility of orthodontic materials. Int J Orthod $19: 833$, 1933.

12) Solomon HA and Reinhard MC : Electric phenomena from dental metals. Dent Survey $9: 23 \sim 25,64 \sim 68,1933$.

13) Macdonald WJ : Chemical and electrogalvanic burns of tongue. N Engl J Med 211 : 585, 1934.

14) Rattner H : Burning tongue. Arch Dermat \& Syph $31:$ 701 702, 1935.

15) Phillips RW, Schnell RJ and Shafer WG : Failure of galvanic current to produce leukoplakia in rats. J Dent Res $47: 666,1968$.

16) Phillips RW : Skinner's science of dental materials. 7th ed. pp 289 300, WB Saunders CO, Philadelphia London and Tronto, 1973.

17) Bergman M, Ginstrup $O$ and Nilner $K$ : Potential and polarization measurements in vivo of oral galvanism. Scand J Dent Res 86 : 135 145, 1978.

18) Lain ES, Shriever $W$ and Caughron GS : Problem of electrogalvanism in the oral cavity caus- 
ed by dissimilar dental metals. J Am Dent Assoc $27:$ 1765 1772, 1940.

19) Mumford JM : Electrolytic action in the mouth and its relationship to pain. J Dent Res 36 : 632 640, 1957.

20）岩田 明：臨床時に使用される各種金属間電位 とその過渡現象について。歯科医学 $35: 2$; 273 395, 1972.

21) Schriever $W$ and Diamond LE : Electromotive forces and electric currents caused by metallic dental fillings. J Dent Res 31 : 205 229, 1952.

22）今野昭義, 伊藤永子, 岡本美孝 : 加齢による唾

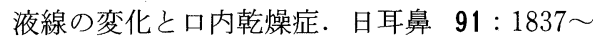
$1846,1988$.

$$
\begin{aligned}
& \text { 原稿受付: 平成 } 2 \text { 年11月14日 } \\
& \text { 原稿採択: 平成 } 3 \text { 年 } 2 \text { 月 } 13 \text { 日 } \\
& \text { 別刷請求先 : 藤原裕美 } \\
& \text { 干734 広島市南区霞1-2-3 } \\
& \text { 広島大学医学部耳鼻咽喉科学教室) }
\end{aligned}
$$

